ANL /ET/CP92764 CONF- $971090--$

\title{
DEVELOPMENT AND PERFORMANCE OF ALUMINUM NITRIDE INSULATING COATINGS FOR APPLICATION IN A LITHIUM ENVIRONMENT*
}

\author{
K. Natesan, C. B. Reed, D. L. Rink, and R. C. Haglund \\ Argonne National Laboratory \\ 9700 South Cass Avenue \\ Argonne, IL 60439 \\ Tel: $\quad(630) 252-5103$ \\ Fax: (630) 252-3604
}

October 1997

\begin{abstract}
The submitted manuscript has been created by the University of Chicago as Operator of Argonne National Laboratory ("Argonne") under Contract No. W-31-109-ENG-38 with the U.S. Department of Energy. The U.S Government retains for itself, and others acting on its behalf, a paid-up, nonexclusive, irrevocable worldwide license in said article to reproduce, prepare derivative works, distribute copies to the public, and pertorm publicly and display publicly, by or on behalf of the Government.
\end{abstract}

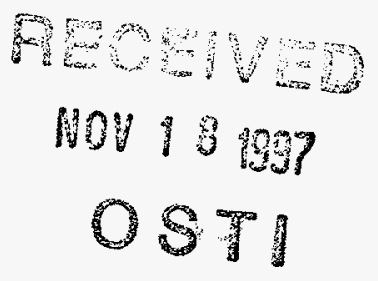

For presentation at Eighth International Conference on Fusion Reactor Materials (ICFRM-8), October 26-31, 1997, Sendai, Japan

*This work has been supported by the U.S. Department of Energy, Office of Fusion Energy Research, under Contract W-31-109-Eng-38. 


\section{DISCLAIMER}

This report was prepared as an account of work sponsored by an agency of the United States Government. Neither the United States Government not any agency thereof, nor any of their employees, makes any warranty, express or implied, or assumes any legal liability or responsibility for the accuracy, completeness, or usefulness of any information, apparatus, product, or process disclosed, or represents that its use would not infringe privately owned rights. Reference herein to any specific commercial product, process, or service by trade name, trademark, manufacturer, or otherwise does not necessarily constitute or imply its endorsement, recommendation, or favoring by the United States Government or any agency thereof. The views and opinions of authors expressed herein do not necessarily state or reflect those of the United States Government or any agency thereof. 


\section{DISCLAMIER}

Portions of this docoment may be illegible in electronic image products. Images are produced from the best available original doccoment. 


\title{
DEVELOPMENT AND PERFORMANCE OF ALUMINUM NITRIDE INSULATING COATINGS FOR APPLICATION IN A LITHIUM ENVIRONMENT
}

\author{
K. Natesan, C. B. Reed, D. L. Rink, and R. C. Haglund \\ Argonne National Laboratory \\ 9700 South Cass Avenue \\ Argonne, IL 60439
}

\begin{abstract}
The blanket system is one of the most important components in a fusion reactor because it has a major impact on both the economics and safety of fusion energy. Based on the requirement that an electrically insulating coating on the first-wall structural material must minimize the magnetohydrodynamic pressure drop that occurs during the flow of liquid metal in a magnetic field, aluminum nitride (AIN) is considered a candidate coating material for the lithium self-cooled blanket concept. Detailed investigations were conducted on the fabrication, metallurgical microstructure, compatibility in liquid Li, and electrical characteristics of AIN as a coating material. A nanoindentation technique was used to evaluate the hardness of the coated samples in as-coated condition, after a hardening treatment, and after exposure to Li. Lithium compatibility studies were conducted in static systems by exposure of AlN-coated specimens for several time periods, at various temperatures, and in various lithium chemistries. Electrical resistance of the specimens was measured at room temperature before and after exposure to liquid $\mathrm{Li}$. This paper discusses the results from ongoing activities on the development of AlN coatings.
\end{abstract}

\section{Introduction}

Lithium-containing liquid metals, e.g., pure $\mathrm{Li}$ or the eutectic $\mathrm{Pb}-17$ at.\% $\mathrm{Li}$ alloy, are attractive breeder materials in fusion reactor blankets. The main challenge in the design of selfcooled blankets is accommodating the strong influence of the magnetic field on the liquid metal flow. It has been shown that even thin conducting walls could lead to a significant pressure drop under fusion reactor blanket conditions. For example, the pressure drop in a poloidal duct in an inboard blanket segment could reach 8.6 MPa if a $0.1-\mathrm{mm}$-thick conducting liner is present [1]. This unacceptably high pressure drop shows the need for electrically insulating coatings that are in contact with the flowing liquid metal. A lower limit for the pressure drop could be achieved with perfectly insulated walls. A perfectly insulating coating on the wall has been shown to decrease the pressure drop from 8.6 to $0.22 \mathrm{MPa}[1,2]$. Malang and Bühler [1] calculated leakage currents through imperfections in coatings and concluded that to obtain an acceptable pressure drop for a fusion blanket, the product of that coating resistivity and the coating layer thickness should have a minimum value of $0.01 \Omega \mathrm{m}^{2}$. The major requirements for a viable insulator coating are chemical compatibility in liquid metal, chemical compatibility with structural metal, adequate electrical insulating characteristics, stability in an irradiation environment, and long-term stability (including self-healing), under thermal-cycling conditions.

An assessment of the thermodynamic stability of nitrides of several structural metals with respect to $\mathrm{N}$ concentration in a $\mathrm{Li}$ environment showed that aluminum nitride (AIN) will be stable in $\mathrm{Li}$ that contains a wide range of $\mathrm{N}$ concentrations [3,4]. For the stability of $\mathrm{AlN}$ in a Li environment, the $\mathrm{N}$ concentration in $\mathrm{Li}$ will be dictated by the $\mathrm{Al}$ concentration in the $\mathrm{Li}$, because both $\mathrm{N}$ and $\mathrm{Al}$ are somewhat highly solubile in $\mathrm{Li}$. Calculations that use the free energy value for the reaction 


$$
\mathrm{AlN}(\text { solid })=\mathrm{Al}(\text { in } \mathrm{Li})+\mathrm{N}(\mathrm{in} \mathrm{Li})
$$

showed that the product of the activities of $\mathrm{N}$ and $\mathrm{Al}$ in $\mathrm{Li}$ required to maintain a stable AlN phase is very low, indicating that dissolution of the AlN will be small (even though the driving force for dissolution of either $\mathrm{N}$ or $\mathrm{Al}$ alone is large based on their solubility values in $\mathrm{Li}$ ). Also, a coating of AlN should be chemically compatible in liquid $\mathrm{Li}$. Furthermore, $\mathrm{Al}$ can be incorporated into the alloy surface by various techniques, and if the coating layer cracks or spalls, the Al-enriched surface could be renitrided by $\mathrm{N}$ dissolved in $\mathrm{Li}$.

A review of available information on electrical resistivity values for several nitrides showed that AlN exhibits resistivities of $>10^{5} \Omega \cdot \mathrm{m}$ at temperatures below $\approx 600^{\circ} \mathrm{C}$. The requirement that the product of the electrical resistivity and the thickness of the coating should exceed a nominal value of $0.01 \Omega \cdot \mathrm{m}^{2}$ translates into a minimum resistivity value of $10^{4} \Omega \cdot \mathrm{m}$ for a coating thickness of $1 \mu \mathrm{m}$, or $10^{3} \Omega \cdot \mathrm{m}$ for a coating thickness of $10 \mu \mathrm{m}$. Based on the resistivity value of AlN, a coating layer of $<1 \mu \mathrm{m}$ would be adequate from the insulating standpoint, provided that resistivity is not reduced during operation, i.e., by irradiation. Figure 1 shows electrical resistances as a function of coating thickness and temperature for several nitride materials, along with the requirements for fusion reactor application.

Several approaches to the development of an AIN coating on the candidate structural material (both in bare and prealuminized conditions) were examined: physical vapor deposition (PVD) with and without bond coats; chemical vapor deposition (CVD); application of a low-temperature electrochemical method that involves sequential reactions; prealuminization of the surface of the alloy and converting it to a nitride in a high-N Li environment; in-situ formation of an AlN coating in $\mathrm{Li}$ with high thermodynamic activities for $\mathrm{Al}$ and $\mathrm{N}$; and prealuminization of specimens of structural material and nitriding them with an $\mathrm{N}_{2}$ cover gas during $\mathrm{Li}$ exposure. An experimental procedure for aluminization of specimens was presented earlier [3-5]. At present, substantial information has been developed on the physical and mechanical characteristics and chemical compatibility of AlN coatings. This paper will discuss the information.

\section{Experimental Procedure}

Gas-Phase Nitridation. Nitridation of $\mathrm{V}-5 \mathrm{Cr}-5 \mathrm{Ti}$ alloy specimens with and without packaluminized surfaces was conducted at 650 and $800^{\circ} \mathrm{C}$ in $\mathrm{NH}_{3} / \mathrm{H}_{2}$ gas mixtures. The experiments were conducted in a thermogravimetric setup with an electrobalance that had a sensitivity of $0.1 \mu \mathrm{g}$ and a loading capacity of $2.5 \mathrm{~g}$. Test coupons, measuring $10 \times 10 \times 1$ to $2 \mathrm{~mm}$, were suspended from the balance by a $200-\mu \mathrm{m}$-diameter $\mathrm{Pt}$ wire and were placed in the constant-temperature section of a vertical three-zone furnace. Weight change of the specimens was monitored continuously and the specimens were examined in detail by several electron-optic and X-ray techniques.

Coatings Deposited by PVD. Aluminum nitride was sputtered reactively. That is, an aluminum target was sputtered in a partial pressure of high-purity $\mathrm{N}$, with Ar as the primary sputtering gas. The process takes place at a relatively low temperature, generally not above $\approx 250^{\circ} \mathrm{C}$. Specimens of bare and prealuminized $\mathrm{V}-5 \mathrm{Cr}-5 \mathrm{Ti}$ and an $\mathrm{Al}$ target were sputter-cleaned for $6 \mathrm{~min}$ with high-purity argon at a flow rate of $45 \mathrm{~cm} 3 / \mathrm{min}$ and a chamber pressure of 20 mtorr. Subsequently, AlN $\mathrm{X}_{\mathrm{X}}$ was sputter-deposited with a $1200-\mathrm{W}$ RF power source for $10 \mathrm{~h}$ in an $\mathrm{Ar} / \mathrm{N}$ gas mixture at a chamber pressure of 23 mtorr. The sputtered specimens were cooled in vacuum overnight, and the second side of the specimens was then coated in the same way.

Coatings Deposited by the Chemical Route. AlN coatings were also deposited by a chemical route with trimethyl aluminum (TMA) and $\mathrm{NH}_{3}$ as the precursor sources of $\mathrm{Al}$ and $\mathrm{N}$, respectively. 
The experimental procedure was as follows: the reaction chamber was flushed with Ar gas; $50 \mathrm{~mL}$ of dry toluene was added by syringe through the septum; then, $10 \mathrm{~mL}$ of TMA was added, also by syringe, taking care to avoid exposure of the pyrophoric TMA to the atmosphere. The solution was heated to $74^{\circ} \mathrm{C}$ while slowly purging the system with argon. Ammonia gas was then passed into the system at a rate of $\approx 45 \mathrm{~mL} / \mathrm{min}$ for $\approx 20 \mathrm{~min}$. The reaction of $\mathrm{NH}_{3}$ with TMA at temperatures above $60^{\circ} \mathrm{C}$ proceeds through adduct formation to give a cyclic trimer with a corresponding loss of methane according to the reactions

$$
3 \mathrm{Me}_{3} \mathrm{Al}+3 \mathrm{NH}_{3} \rightarrow 3 \mathrm{Me} 3 \mathrm{Al} \cdot \mathrm{NH}_{3} \rightarrow\left(\mathrm{Me}_{2} \mathrm{Al} \cdot \mathrm{NH}_{2}\right)_{3}+3 \mathrm{CH}_{4} \text {. }
$$

These reactions are exothermic, and temperature increases of $20-30^{\circ} \mathrm{C}$ were observed. Completion of the reaction corresponded to cessation of the exotherm. Evaporation of the toluene leaves the trimer as a crystalline white solid that melts to a clear, colorless liquid upon heating to $135^{\circ} \mathrm{C}$. A coupon of $\mathrm{V}$ alloy was immersed in the liquid trimer for $\approx 30 \mathrm{~s}$, raised out of the melt, and heated stepwise to drive off methane and convert the intermediate to AIN. Air was excluded during the heating process. Nitrogen was passed through the system, and the setup was held at $150^{\circ} \mathrm{C}$ for $20 \mathrm{~min}$. During this period, the liquid trimer was converted to a solid, while methane was evolved. Methane evolution continued as the coated coupon was heated to $170^{\circ} \mathrm{C}$ for $25 \mathrm{~min}$, then to $200^{\circ} \mathrm{C}$ for $30 \mathrm{~min}$, and finally to $500^{\circ} \mathrm{C}$ for $24 \mathrm{~h}$. The coatings were examined by scanning electron microscopy (SEM) and X-ray diffraction (XRD).

Chemical Vapor Deposition. Preliminary studies were conducted to evaluate deposition of AlN by CVD, an approach that has been shown capable of developing very thin electrical insulator coatings for semiconductor applications. The advantage of CVD is that the coating is applied from a gas-phase reaction rather than by line-of-sight application as in the PVD method, and, as a result, can be used to coat components with complex shapes. Because CVD requires fairly high temperatures $\left(800-900^{\circ} \mathrm{C}\right)$, one must establish whether AIN can be deposited by CVD without degrading the properties of the substrate. To address this question, coupon specimens of $\mathrm{V}-5 \mathrm{Cr}$ $5 \mathrm{Ti}$ were coated by a combination of thermal and plasma-assisted processing at $600-800^{\circ} \mathrm{C}$.

Liquid Metal Exposures. Two static liquid Li systems were designed and fabricated for studies on the compatibility of insulator coatings. The systems were filled with $\approx 15 \mathrm{~L}$ of highpurity (99.97 wt.\%) Li. The concentration of trace impurities of $\mathrm{Na}, \mathrm{Ca}, \mathrm{K}, \mathrm{Fe}, \mathrm{Si}$, and $\mathrm{Cl}$ in the $\mathrm{Li}$ was $<50 \mathrm{ppm}$, and $\mathrm{N}$ concentration in the $\mathrm{Li}$ was $80 \mathrm{ppm}$. The temperatures of both systems were set at 300 and $/$ or $500^{\circ} \mathrm{C}$ to examine the compatibility of the insulator coatings. In one of the $\mathrm{Li}$ systems, $\mathrm{N}_{2}$ was bubbled through a small tube immersed in the $\mathrm{Li}$ to increase the concentration of $\mathrm{N}$ in the $\mathrm{Li}$.

Coupon specimens of AlN-coated samples were exposed in the liquid $\mathrm{Li}$. Weight change was measured to establish the rate of corrosion of the coatings as a function of time and liquid metal temperature and chemistry. After exposure, the specimens were examined by SEM, energy dispersive X-ray (EDX) analysis, and XRD. The coated specimens were examined to evaluate coating integrity after exposure to liquid $\mathrm{Li}$, microstructural changes in the coatings, coating/substrate interactions and bonding, and electrical insulation characteristics of the coatings.

\section{Results and Discussion}

Gas Phase Nitrided Specimens. The nitridation process followed a parabolic rate expression for both bare and prealuminized alloys. The parabolic rate constants for nitridation of bare $\mathrm{V}-5 \mathrm{Cr}$ $5 \mathrm{Ti}$ alloy were $9.1 \times 10^{-6}$ and $6.9 \times 10^{-7} \mathrm{mg}^{2} \mathrm{~cm}^{-4} \mathrm{~s}^{-1}$ at 800 and $600^{\circ} \mathrm{C}$, respectively. A detailed examination of the surfaces and cross sections of nitrided specimens showed V-rich nitrides. The 
results indicated that $\mathrm{N}$ enrichment via gas-phase nitridation is possible but that an exclusive binary nitride layer of $\mathrm{V}$ was not observed. The rate constant for nitridation of prealuminized $\mathrm{V}-5 \mathrm{Cr}-5 \mathrm{Ti}$ alloy was $2.2 \times 10^{-8} \mathrm{mg}^{2} \mathrm{~cm}^{-4} \mathrm{~s}^{-1}$, which is lower than the rate constant for nitridation of the bare alloy; however, the surface and subsurface regions consisted predominantly of $\mathrm{V}$-rich nitride and not AIN.

Calculation of the thermodynamic stability of several oxides indicates that the $O$ partial pressures should be $<10^{-40} \mathrm{~atm}$ at $650^{\circ} \mathrm{C}$ to prevent formation of the $\mathrm{V}_{9} \mathrm{O}$ phase. The pressures needed to prevent formation of oxides of $\mathrm{Ti}$ and $\mathrm{Al}$ are lower by a few orders of magnitude. Such low $O$ partial pressures will be difficult to achieve in experiments that involve flowing gas, even if the gases are purified by hot gettering. Another consideration for the formation of a "pure" binary nitride such as AIN is that the required partial pressures of $\mathrm{N}$ in the exposure environment are extremely low. The calculations showed that, to obtain the AlN phase by gas-phase nitridation, the ratio $\mathrm{NH}_{3} / \mathrm{H}_{2}{ }^{3 / 2}$ must be $<10^{-18}$ and $10^{-12}$ at 800 and $400^{\circ} \mathrm{C}$, respectively. Such low values cannot be maintained experimentally because even a $\mathrm{H}_{2} / \mathrm{NH}_{3}$ mixture that contains $1 \mathrm{vppm} \mathrm{NH}_{3}$ can only result in a value of $\approx 10^{-6}$ for the ratio. Based on the experimental data developed with gas-phase reactions and on the analysis of data, it is concluded that gas-phase nitridation is not a viable method for developing electrically insulating AIN coatings.

PVD-AIN-Coated Specimens. The AIN layers of V-alloy specimens coated by PVD were fairly compact and of uniform thickness in the ranges of 8-12 $\mu \mathrm{m}$. XRD analysis showed hexagonal AlN phase with a (002) orientation [3]. No vanadium nitride $\left(\mathrm{V}_{2} \mathrm{~N}\right)$ was detected because the temperature of the substrate was $<200^{\circ} \mathrm{C}$ during the coating process. Even though the coatings were fairly adherent, early exposure of these coated specimens to Li resulted in complete disappearance of the coating layer by either spallation or dissolution. As a result, the coated specimens were subjected to a thermal-hardening treatment at $700-900^{\circ} \mathrm{C}$ prior to exposure in $\mathrm{Li}$. XRD of these heat-treated specimens also showed hexagonal AlN phase with (002) orientation, but traces of the $\mathrm{V}_{2} \mathrm{~N}$ phase were noted because of a reaction between AlN and $\mathrm{V}$ at the coating/substrate interface.

CVD-AIN-Coated Specimens. Very few samples were coated by CVD because the primary purpose of the effort was to evaluate the feasibility of the approach rather than to make dense, thick coatings. In general, the coatings prepared by CVD were fairly thin and exhibited significant cracking. XRD analysis of the coated specimen showed some weak lines of AlN, but the specimen was not examined further. Because the coatings exhibited significant cracking, electrical resistivity of these coated samples was not measured, nor were the samples used in Li exposure experiments. The preliminary results for the CVD approach showed that the probability of producing good coatings is quite high, but significant additional work is needed to experiment with the coating parameters and to develop dense, adherent coatings.

Coatings Deposited by the Chemical Route. Even though the chemical route followed the general procedure described earlier, several runs were conducted to examine the effect of various coating parameters on coating integrity. In some experiments, coupons were immersed in just enough liquid cyclic trimer precursor to cover the coupon surface, and the entire mass was then heated to convert the precursor to a solid. The coatings produced by this procedure were thick but they were heavily cracked and adhered weakly to the substrate. In another experiment, a coupon was immersed briefly in the molten precursor, removed, and heated to convert the film of precursor to a coating of AIN. Formation of AlN was confirmed and, in most cases, the coatings were optically transparent. Although severe cracking was observed in thick coatings, the thin coatings appeared to be crack-free. In an attempt to determine the cause of the cracking, two coating runs were prematurely arrested after a brief low-temperature $\left(200^{\circ} \mathrm{C}\right)$ annealing that should 
have driven off most of the methane byproduct. The coatings cracked at this stage, proving that the cracking occurs fairly early in the pyrolysis. The cause of cracking may be due to shrinking of the coatings as the composition changes toward AIN, or it may be due to methane evolution within the thicker coatings. XRD patterns of the coated coupons showed peaks that correspond to the substrate alloy and several weak peaks that match the X-ray pattern of hexagonal AIN. The chemical approach requires significant additional effort to obtain crack-free, fairly thick $(10-20 \mu \mathrm{m})$ AlN coatings.

Electrical Insulating Behavior of As-Coated Coatings. The electrical resistance of several of the AlN-coated specimens was measured by sputter-deposition (in a vacuum chamber) of pure Au in a grid form by masking the sample to control the area of Au deposition. Coating resistance was measured at room temperature at several $\mathrm{Au}$-coated locations. Because the Au-deposited areas are known, the measured resistance at various locations can be used to calculate the product of resistivity and thickness, which should be $>0.01 \Omega \cdot \mathrm{m}^{2}$ or $100 \Omega \cdot \mathrm{cm}^{2}$. Because only the PVD technique yielded adherent, crack-free AlN coatings, the electrical resistance of several of these coated specimens was measured. The measured values of electrical resistance at several locations on bare and prealuminized specimens in as-coated condition and after a hardening treatment were orders of magnitude higher than needed for blanket application [4,5].

Lithium Compatibility of Coatings. Lithium compatibility tests were conducted primarily with specimens that were coated with AlN by PVD. The coatings developed by other techniques were neither crack-free nor of adequate mechanical integrity for exposure to Li. AlN-coated specimens were exposed to two Li environments, characterized by normal purity and containing higher $\mathrm{N}$ obtained by bubbling a $\mathrm{N}_{2} / \mathrm{Ar}$ gas mixture into Li. Table 1 lists the tests that were performed and details on the objectives of the various exposure runs, exposure times and temperatures, specimens exposed, and results obtained from some of the experiments performed in $\mathrm{Li}$.

Early exposures of AlN-coated specimens to Li showed that the specimens in as-coated condition exhibited poor bonding between the coating and substrate and that a hardening of the coating at elevated temperature may be necessary to improve adhesion. As a result, we attempted a thermal/chemical hardening treatment in which the AlN-coated specimens were heated to 700 $900^{\circ} \mathrm{C}$ in a controlled environment prior to exposure to the $\mathrm{Li}$ environment. Such an approach seemed to harden the coating, as evidenced by substantial improvement in the scratch resistance of the coating surface. Several AlN-coated specimens of V-5Cr-5Ti alloy that were subjected to the $900^{\circ} \mathrm{C}$ hardening treatment were prepared and exposed to $\mathrm{Li}$ for $600 \mathrm{~h}$ at $300^{\circ} \mathrm{C}$ in Run $2-8$. As shown in Table 1 , all of the specimens performed well in $\mathrm{Li}$ and the coatings exhibited high resistance values. In contrast, the resistance of a sample with a bond coating of $\mathrm{TiN}$ was significantly low after Li exposure. After Li exposure, EDX analysis revealed that the coating surface exhibited a reaction product that contained only $\mathrm{Al}$ and $\mathrm{O}$. XRD analysis of the three specimens showed hexagonal $\mathrm{AlN}$ as the predominant phase in all three specimens; no $\mathrm{Li}, \mathrm{Al}, \mathrm{O}$, and/or $\mathrm{N}$ compounds were observed. Because these Li-exposed specimens were cleaned in alcohol and water prior to analysis, all of the Li-containing compounds would have dissolved in water and none would be expected in the analysis.

To examine whether similar insulating characteristics can be maintained in Li by coatings that were subjected to hardening at a lower temperature, several specimens were prepared with a thermal/chemical treatment at $700^{\circ} \mathrm{C}$ (instead of $900^{\circ} \mathrm{C}$ ) for $284 \mathrm{~h}$. The specimens were subsequently exposed to Li for $456 \mathrm{~h}$ at $300^{\circ} \mathrm{C}$ in Run 2-9. The AlN-coated specimen of the V alloy exhibited good insulating characteristics; the coating on a prealuminized $\mathrm{V}$ alloy showed high resistance on only one side of the specimen while the other side exhibited flaking and cracking of the coating. The specimen with a bond coating of TiN exhibited almost no resistance, as indicated 
by the complete loss of coating during $\mathrm{Li}$ exposure. The lower hardening temperature seemed to reduce the reaction between the coating and the $\mathrm{Li}$ environment, as evidenced by the thinner layer of the reaction product and also by the lack of continuous coverage of the coating.

A long-term endurance test was conducted in Run 2-10 by exposing specimens of $\mathrm{V}$ alloy with and without prealuminization, AlN coated samples of $\mathrm{V}$ alloy with and without prealuminization, and a prealuminized Type 304 stainless steel pipe sample with a pack-diffusion $\mathrm{Al}_{2} \mathrm{O}_{3}$ coating to $\mathrm{Li}$ for $5000 \mathrm{~h}$ at $300^{\circ} \mathrm{C}$. Figure 2 shows SEM photomicrographs of specimens after a 5000-h exposure to Li. The AlN-coated specimens exhibited high resistance after exposure to $\mathrm{Li}$, and the $\mathrm{Al}_{2} \mathrm{O}_{3}$-coated stainless steel specimen lost the coating in $\mathrm{Li}$.

In Run 3-5, several AIN-coated specimens were exposed to $\mathrm{Li}$ at $300^{\circ} \mathrm{C}$ for $480 \mathrm{~h}$. As before, coating with thermal/chemical treatment exhibited insulating characteristics. Run 3-6 is analogous to Run $2-9$ in that the $\mathrm{AlN}$-coated specimens were pretreated at $700^{\circ} \mathrm{C}$ prior to $\mathrm{Li}$ exposure. The results showed that the coating on the $V$ alloy had adequate resistance, whereas the coated prealuminized $\mathrm{V}$ alloy exhibited high resistance on only one side of the specimen.

Hardness of AlN Coatings. An ultralow-load indentation method that involved a nanoindenter was used to evaluate the hardness of several as-coated and Li-exposed specimens. The instrument is a mechanically highly sensitive microprobe capable of sensing both load and displacement continuously as indents are made in a sample. Details on the test procedure and hardness calculations are presented elsewhare [4]. Several samples were analyzed by the nanoindentation technique, and for each indent, unloading curves were generated after total displacements of 40,80 , and $150 \mathrm{~nm}$. The results showed that substrate hardness of samples without prealuminization is $14-17 \mathrm{GPa}$; values for the prealuminized samples are 7-8.5 $\mathrm{GPa}$ which correspond to an Al-rich zone of the V alloy. The hardness of the AlN coating after $900^{\circ} \mathrm{C}$ treatment but without $\mathrm{Li}$ exposure showed higher values (28-31 GPa) for the specimen that was not prealuminized than the values (20-24 GPa) for the specimens that were prealuminized.

For specimens exposed to $\mathrm{Li}$ in Run $2-8$, the difference between the hardness of the coating and that of the substrate in the specimen without prealuminization is small (2-3 GPa) and may be responsible for the improved adhesion of the coating to the substrate. In the prealuminized specimen exposed in the same Li, the difference between the hardness of the coating and that of the substrate is 14-16 GPa. In the case of specimens exposed in Run 2-9, the pretreatment temperature was $700^{\circ} \mathrm{C}$ and the hardness of the coating, even after $\mathrm{Li}$ exposure, is high for the specimen without prealuminization than that of the specimen that was prealuminized. This seems to indicate that the absolute values of the hardness for the coating, rather than the difference in hardness between coating and substrate, may play a role in adhesion and spallation.

Electrical Resistance of Li-Exposed AlN Coatings. After examination of the physical and chemical characteristics of the coatings and the coating integrity of as-coated and hardened specimens after exposure to Li environments was completed. We measured the electrical resistance of the Li-exposed, initially coated specimens and compared the measured values with the minimum values required for application in fusion reactors. For this purpose, several specimens were selected for resistance measurements. Specimens included those that were initially bare and prealuminized, those with coatings from differing sources, with differing hardening treatment, and several exposure times in $\mathrm{Li}$ environments. After the specimens were masked and Au-plated, resistances were measured at room temperature. Measured resistance values from several specimens, at differing locations within the same specimen exceeded the minimum value for the resistance required for application in a fusion reactor blanket [4,5].

In-Situ Development of AlN Ccatings in Li. Even though AIN coatings developed by PVD 
had potential as electrically insulating coatings, the ultimate objective is to develop the coating in situ in Li by controlling the activity of $\mathrm{N}$ and/or Al. To examine this approach, we attempted to increase the $\mathrm{N}$ and $\mathrm{Al}$ activity in Li by adding $100 \mathrm{~g}$ of fine AIN powder at $300^{\circ} \mathrm{C}$ and by heating the $\mathrm{Li}$ to $500^{\circ} \mathrm{C}$ for $24 \mathrm{~h}$ to equilibrate the $\mathrm{Li}$ with dissolved $\mathrm{Al}$ and $\mathrm{N}$. In Run 3-7, specimens of $\mathrm{V}$ alloy with and without prealuminization and AIN coatings in as-coated condition were exposed to $\mathrm{Li}$ for 24 and $620 \mathrm{~h}$ to examine whether $\mathrm{N}$ and/or $\mathrm{Al}$ were transferred to the alloy surface or whether the coating reacted with $\mathrm{Li}$. The results showed no significant transfer of either $\mathrm{N}$ or $\mathrm{Al}$ from $\mathrm{Li}$ to the alloy, as evidenced by resistance measurements and SEM analysis of the specimens. The specimen coatings were insulating on one side of the specimen but tended to flake off from the other side of the specimens. Based on these results, we concluded that the dissociation of AlN in Li may be a slow process, even at $500^{\circ} \mathrm{C}$, and that an alternate method is needed to increase the activity of $\mathrm{N}$ and $\mathrm{Al}$.

Because $\mathrm{Al}$ and $\mathrm{N}$ are highly soluble in liquid $\mathrm{Li}$, an increase in the activity of these elements in $\mathrm{Li}$ was obtained by addition of solid $\mathrm{Al}$ and $\mathrm{Li}_{3} \mathrm{~N}$. Additions of $14.2 \mathrm{~g}$ of $\mathrm{Al}$ and $25.5 \mathrm{~g} \mathrm{Li} 3 \mathrm{~N}$ yielded $\mathrm{Al}$ and $\mathrm{N}$ concentrations of 4057 and 2929 wppm, respectively. Even if all of the $\mathrm{Al}$ reacted to form AIN, N concentration in $\mathrm{Li}$ in excess of AIN was $825 \mathrm{ppm}$. Subsequent to these additions, the $\mathrm{Li}$ was maintained at $500^{\circ} \mathrm{C}$ for $120 \mathrm{~h}$ to equilibrate the system. Specimens of $\mathrm{V}$ alloy with and without prealuminization and several specimens of thermally/chemically treated AIN coatings on a V alloy substrate were exposed to $\mathrm{Li}$ for $120 \mathrm{~h}$ at $500^{\circ} \mathrm{C}$ in Run 3-8. Two major observations were noted from a detailed analysis of the exposed specimens from this run. The first was that no transfer of either $\mathrm{N}$ or $\mathrm{Al}$ was observed from $\mathrm{Li}$ toward the bare and prealuminized $\mathrm{V}$ alloy specimens. The second observation was that the thermally treated coatings of AlN performed well and exhibited high resistivity values. Furthermore, no surface reactions were noted between the coating and the $\mathrm{Li}$ or the impurities in $\mathrm{Li}$, even though the temperature was as high as $500^{\circ} \mathrm{C}$. Figure 3 shows SEM photomicrographs of several AlN-coated specimens tested in Run 3-8.

Subsequently, the $\mathrm{Li}$ temperature in the vessel was lowered to $300^{\circ} \mathrm{C}$ and additional specimens of $\mathrm{V}$ alloy with and without prealuminization, several thermally/chemically treated AlNcoated specimens, and a "hot-dip" Al-coated V alloy specimen were exposed to Li for $120 \mathrm{~h}$ in Run 3-9. For the same concentration of $\mathrm{N}$ and $\mathrm{Al}$ in $\mathrm{Li}$, the thermodynamic activities of these elements in $\mathrm{Li}$ will be much higher at $300^{\circ} \mathrm{C}$ than at $500^{\circ} \mathrm{C}$. Analysis of exposed specimens still showed no transfer of $\mathrm{N}$ or $\mathrm{Al}$ to the $\mathrm{V}$ alloy specimens. All of the AlN-coated specimens performed well in terms of physical characteristics and all of them exhibited high electrical resistivity. The hot-dip specimen, which initially had a poorly adhered Al layer, exhibited complete loss of $\mathrm{Al}$ from the surface after exposure to $\mathrm{Li}$.

A significant difference is seen in the microstructures of the coatings of specimens that were exposed to normal-purity $\mathrm{Li}$ and those exposed in $\mathrm{Li}$ that contained deliberate additions of $\mathrm{Al}$ and $\mathrm{N}$. In the former, the surface regions of the coatings reacted with $\mathrm{Li}$ or impurities in $\mathrm{Li}$, to produce a layer that was rich in $\mathrm{O}, \mathrm{Al}$, and probably $\mathrm{Li}$. In the case of specimens exposed to $\mathrm{Li}$ that contained added $\mathrm{N}$ and $\mathrm{Al}$. no such layer was observed.

To examine the thermodynamic stability of AIN in $\mathrm{Li}$ and the possible reactions between the AlN coating and $\mathrm{O}$ in $\mathrm{Li}$, calculations were made to evaluate, in terms of $\mathrm{O}$ and $\mathrm{N}$ in $\mathrm{Li}$, the regions in which AlN will be stable when in contact with $\mathrm{Li}$. AlN can react with $\mathrm{O}$ in $\mathrm{Li}$ via three possible reactions:

$$
\begin{aligned}
& 5 \mathrm{AIN}(\mathrm{s})+8 \mathrm{O}(\mathrm{Li})+\mathrm{Li}(\mathrm{l})=\mathrm{LiAl}_{5} \mathrm{O}_{8}+5 \mathrm{~N}(\mathrm{Li}) \\
& \mathrm{AIN}(\mathrm{s})+2 \mathrm{O}(\mathrm{Li})+\mathrm{Li}(\mathrm{l})=\mathrm{LiAlO}_{2}+\mathrm{N}(\mathrm{Li})
\end{aligned}
$$




$$
2 \mathrm{AIN}(\mathrm{s})+3 \mathrm{O}(\mathrm{Li})+\mathrm{Li}(\mathrm{l})=\mathrm{Al}_{2} \mathrm{O}_{3}+2 \mathrm{~N}(\mathrm{Li})
$$

Based on knowledge of the free energy of formation of AIN and various oxides, calculations were made to establish the minimum $\mathrm{N}$ concentration in $\mathrm{Li}$ that is required for $\mathrm{AlN}$ to be stable at several $\mathrm{O}$ concentrations in $\mathrm{Li}$. Figure 4 shows plots of $\mathrm{N}$ concentration as a function of temperature for reactions $2-4$ at $\mathrm{O}$ levels of $1,10,100$, and $1000 \mathrm{wppm}$ in $\mathrm{Li}$. Also shown in the figure is a curve for the $\mathrm{O}$ level in $\mathrm{Li}$ that corresponds to a cold-trap temperature of $200^{\circ} \mathrm{C}$. In these plots, for a given concentration of $\mathrm{O}$ in $\mathrm{Li}, \mathrm{AlN}$ will be stable in the region above the curve and the oxide phase will be stable in the region below the curve. The curves also indicate that for a given temperature and at a given concentration of $\mathrm{O}$ in $\mathrm{Li}$, there exists a definite concentration of $\mathrm{N}$ in $\mathrm{Li}$ below which the oxidation of AIN will occur. For example, based on reactions 2,3 , and 4 at $300^{\circ} \mathrm{C}$ and $100 \mathrm{ppm} \mathrm{O}$ in $\mathrm{Li}$, the minirnum $\mathrm{N}$ concentration needed to maintain stable AlN is 5000 , 4000 , and $0.1 \mathrm{wppm}$, respectively. In normal-purity (without a cold trap) $\mathrm{Li}$, the $\mathrm{O}$ and $\mathrm{N}$ concentrations are generally $\approx 100$ wppm each.

Under these conditions, the AIN coating will not react to form $\mathrm{Al}_{2} \mathrm{O}_{3}$ but will react to form either $\mathrm{LiAl}_{5} \mathrm{O}_{8}$ or $\mathrm{LiAlO}_{2}$. This confirms the SEM and EDX analysis of the reaction phases observed in the present experiments. The calculations also indicate that at the higher temperature of $500^{\circ} \mathrm{C}$ and a concentration of $\mathrm{O}$ in $\mathrm{Li}$ of $100 \mathrm{wppm}$, the $\mathrm{N}$ concentrations in $\mathrm{Li}$ needed to maintain AlN as a stable phase are 900,200 , and $0.08 \mathrm{ppm}$, based on reactions 2, 3, and 4, respectively. The data also show that at $500^{\circ} \mathrm{C}$ and for an $\mathrm{O}$ concentration in $\mathrm{Li}$ cold-trapped at $200^{\circ} \mathrm{C}$, the $\mathrm{N}$ concentrations are 180,30 , and 0.02 wppm, based on reactions (2), (3), and (4), respectively. These calculations clearly demonstrate the importance of controlling and maintaining low $O$ levels in $\mathrm{Li}$ for the nitride coating to perform adequately. Furthermore, such control of $\mathrm{O}$ in $\mathrm{Li}$ is essential for the in-situ development of $\mathrm{AlN}$ coatings by transfer of $\mathrm{Al}$ and $\mathrm{N}$ from $\mathrm{Li}$ to the $\mathrm{V}$ alloy surface. The calculations also indicate the importance of experiments in a flowing system, in which the impurity levels can be effectively controlled by a cold trap, in contrast to experiments in either small capsules or in static vessels, as in the present experiments.

\section{Summary}

Detailed investigations were conducted on the fabrication, metallurgical microstructure, compatibility with liquid $\mathrm{Li}$, and electrical characteristics of AIN as a coating material. Several conclusion can be drawn from the study.

Coatings of AIN on a V alloy substrate can be successfully prepared by PVD. Processes that use CVD and chemical routes have potential, but substantial additional effort is needed to obtain reliable, crack-free coatings. Gas-phase nitridation has limitations unless the $O$ content of the exposure environment is substantially reduced.

Coatings developed by PVD need a thermal/chemical hardening treatment to improve the adhesion characteristics and probably reduce the porosity of the coatings. Coating characteristics may be improved if the substrate temperature is increased during the coating process.

Experiments conducted with PVD-developed AIN coatings showed adequate chemical compatibility in normal-purity Li. They also retained their insulating properties after exposure to $\mathrm{Li}$. However, the coating surfaces reacted with $\mathrm{Li}$ to form ternary oxides of $\mathrm{Li}, \mathrm{Al}$, and $\mathrm{O}$. The growth rates of these oxides have not been established.

An endurance test of $5000 \mathrm{~h}$ exposure in normal-purity Li showed the AlN coating to be adherent and have high resistance after $\mathrm{Li}$ exposure. 
Within the range of the present study, the effect of increased $\mathrm{N}$ content in the Li environment on the coating performance was minimal.

Hardness measurements made by nanoindentation seem to indicate that the absolute values of the hardness of the coating, rather than the difference in hardness between the coating and the substrate, may play a role in adhesion and spallation.

Significant additional effort must be expended to study the in-situ measurement of coating resistance; the concentration of impurities such as $\mathrm{O}$ in the coating and thermal-cycling effects are considered important.

The study of in-situ development of AlN coatings in Li must be extended. It has been established that, for a given exposure temperature and concentration of $\mathrm{O}$ in $\mathrm{Li}$, there exists a minimum concentration of $\mathrm{N}$ in Li below which the AlN will react to form binary or ternary oxides with $\mathrm{Li}$ and $\mathrm{Al}$. This minimum $\mathrm{N}$ concentration decreases with increasing temperature.

\section{Acknowledgments}

The authors thank J. Kammer of Midwest Research Technologies, M. Graham, C. West, and G. Nichols of Industrial Research Laboratories of Northwestern University, for assistance in developing and/or supplying of coated specimens. At Argonne National Laboratory, B. Tani and M. Lanagan assisted with X-ray diffraction analysis of specimens. This work has been supported by the U.S. Department of Energy, Office of Fusion Energy Research, under Contract W-31-109Eng-38.

\section{References}

[1]. S. Malang and L. Bühler, "MHD pressure drop in ducts with imperfectly insulating coatings," Argonne National Laboratory Report ANL/FPP/TM-269 (Aug. 1994).

[2]. S. Malang, H. U. Borgstedt, E. H. Farnum, K. Natesan, and I. V. Vitkovski, "Development of insulating coatings for liquid metal blankets," Fusion Eng. Design, 27, p. 570 (1995).

[3]. K. Natesan, "Development of aluminum nitride insulator coatings for fusion reactor applications," Argonne National LAboratory ANL/FPP/TM-278 (1995).

[4]. K. Natesan and D. L. Rink, "Physical and mechanical characteristics and chemical compatibility of aluminum nitride insulator coatings for fusion reactor applications," Argonne National LAboratory Report ANL/FPP/TM-290 (1996).

[5]. K. Natesan, "Fabrication and performance of AlN insulator coatings for application in fusion reactor blankets," J. Nucl. Mater., 233-237, p. 1403 (1996). 
Table 1. Experiments performed in $\mathrm{Li}$ of normal purity and in $\mathrm{N}$-enriched $\mathrm{Li}$

\begin{tabular}{|c|c|c|c|c|c|c|}
\hline Run No. ${ }^{a}$ & $\begin{array}{l}\text { Temp. } \\
\left({ }^{\circ} \mathrm{C}\right)\end{array}$ & $\begin{array}{l}\text { Exposure } \\
\text { time (h) }\end{array}$ & Objective & $\begin{array}{l}\text { Specimens } \\
\text { exposed }\end{array}$ & $\begin{array}{c}\text { Wt. loss (mg mn } \\
\text { and } \\
\text { Electrical behavi }\end{array}$ & $\begin{array}{l}\mathrm{m}^{-2} \mathrm{I} \\
\text { vior }\end{array}$ \\
\hline $2-8$ & 300 & 600 & $\begin{array}{l}\text { Evaluation of AlN } \\
\text { coatings with } \\
\text { pretreatment at } 900^{\circ} \mathrm{C}\end{array}$ & 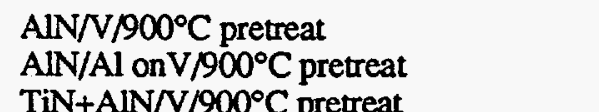 & $\begin{array}{l}0.0168 \\
0.006 \\
0.0088\end{array}$ & $\begin{array}{l}\mathbf{R} \\
\mathbf{R} \\
\mathbf{C}\end{array}$ \\
\hline $2-9$ & 300 & 456 & $\begin{array}{l}\text { Evaluation of AlN } \\
\text { coatings with } \\
\text { pretreatment at: } 700^{\circ} \mathrm{C} \\
\text { for } 284 \mathrm{~h}\end{array}$ & $\begin{array}{l}\text { AlN/V } / 700^{\circ} \mathrm{C} \text { pretreat } \\
\text { AlN/Al onV } 700^{\circ} \mathrm{C} \text { pretreat } \\
\text { TiN+AlN } / \mathrm{V} / 700^{\circ} \mathrm{C} \text { pretreat }\end{array}$ & $\begin{array}{l}0.0 \text { woo } \\
0.016 \\
0.046 \\
0.012\end{array}$ & $\begin{array}{r}\mathbf{R} \\
\mathbf{R} \\
\mathbf{C}\end{array}$ \\
\hline $2-10$ & 300 & 5000 & $\begin{array}{l}\text { Long-term } \\
\text { performance of } \\
\text { preformed } \mathrm{AIN} \text { and } \\
\mathrm{Al}_{2} \mathrm{O}_{3} \text { coatings at } \\
300^{\circ} \mathrm{C} \text { in } \mathrm{Li}\end{array}$ & $\begin{array}{l}\text { AlN/V as-coated } \\
\text { AlN/Alum. } V \text { as-coated } \\
\text { AlN/V/900 } \\
\text { AlN/Alum.V pretreat } \\
\mathrm{Al}_{2} \mathrm{O}_{3} \text { coating on } 304 \mathrm{SS}\end{array}$ & $\begin{array}{l}0.0436 \\
0.0121 \\
0.0261 \\
0.0258 \\
0.0179\end{array}$ & $\begin{array}{l}\mathrm{C} \\
\mathrm{C} \\
\mathrm{R} \\
\mathrm{R} \\
\mathrm{C}\end{array}$ \\
\hline $3-5$ & 300 & 480 & $\begin{array}{l}\text { Evaluation of AlN } \\
\text { coatings with } 900^{\circ} \mathrm{C} \\
\text { pretreatment }\end{array}$ & $\begin{array}{l}\text { V/AlN with } 900^{\circ} \mathrm{C} \text { pretreat } \\
\text { AlN bulk }\end{array}$ & $\begin{array}{l}0.009 \\
0.004\end{array}$ & $\begin{array}{l}\mathbf{R} \\
\mathbf{R}\end{array}$ \\
\hline $3-6$ & 300 & 456 & $\begin{array}{l}\text { Evaluation of AlN } \\
\text { coatings with } 700^{\circ} \mathrm{C} \\
\text { pretreatment }\end{array}$ & $\begin{array}{l}\text { V/AIN with } 700^{\circ} \mathrm{C} \text { pretreat } \\
\text { Alum. V/AIN } 700^{\circ} \mathrm{C} \text { pretreat }\end{array}$ & $\begin{array}{l}0.0355 \\
0.027 \text { partially }\end{array}$ & $\begin{array}{r}\mathbf{R} \\
\mathbf{l} \mathbf{R}\end{array}$ \\
\hline $3-7^{c}$ & 300 & 24,620 & $\begin{array}{l}\text { Evaluate transport of } \\
\text { Al and/or } \mathrm{N} \text { by additon } \\
\text { of AlN powder to Li }\end{array}$ & $\begin{array}{l}\text { V -5Cr-5Ti (no coating) } \\
\text { Alum. V alloy (no coating) } \\
\text { As-coated AlN on V alloy }\end{array}$ & \multicolumn{2}{|c|}{$\begin{array}{l}\text { bare: } 0 \Omega \\
\text { Al/V: } 2-5 \Omega \\
\text { High } R \text { on one side, } \\
\text { flaking on other side }\end{array}$} \\
\hline $3-8^{d}$ & 500 & 120 & $\begin{array}{l}\text { Evaluation of in-situ } \\
\text { coating of AlN on V } \\
\text { alloy and preccoated } \\
\text { samples at } 500^{\circ} \mathrm{C} \text { after } \\
\mathrm{Al} \text { and Li3 } \mathrm{N} \text { addition } \\
\text { to } \mathrm{Li}\end{array}$ & $\begin{array}{l}\text { V }-5 \mathrm{Cr}-5 \mathrm{Ti} \\
\text { Alum. V alloy } \\
\text { V/AlN with } 900^{\circ} \mathrm{C} \text { pretreat } \\
\text { V/AIN (coated on one side) with } 900^{\circ} \mathrm{C} \\
\text { pretreat }\end{array}$ & $\begin{array}{l}\text { coated side: } \\
\text { uncoated side }\end{array}$ & $\begin{array}{l}\mathrm{C} \\
\mathrm{C} \\
\mathrm{R} \\
\mathrm{R} \\
\mathrm{C}\end{array}$ \\
\hline $3-9$ & 300 & 120 & $\begin{array}{l}\text { Evaluation of in-situ } \\
\text { coating of AlN on V } \\
\text { alloy and preccoated } \\
\text { samples at } 300^{\circ} \mathrm{C}\end{array}$ & $\begin{array}{l}\text { V }-5 \mathrm{Cr}-5 \mathrm{Ti} \\
\text { Alum. V alloy } \\
\text { V/AlN with } 900^{\circ} \mathrm{C} \text { pretreat } \\
\text { V/AIN (coated on one side) with } 900^{\circ} \mathrm{C} \\
\text { pretreat ( } 2 \text { samples) } \\
\text { "Hot dip" Al on V alloy (KfK, Germany) }\end{array}$ & $\begin{array}{l}\text { coated side: } \\
\text { uncoated side: }\end{array}$ & $\begin{array}{l}\mathrm{C} \\
\mathrm{C} \\
\mathrm{R} \\
\mathrm{R} \\
\mathrm{C} \\
\mathrm{C}\end{array}$ \\
\hline
\end{tabular}

aRun numbers that start with 2 indicate normal-purity $\mathrm{Li}$; those that start with 3 indicate $\mathrm{N}$-enriched $\mathrm{Li}$.

$\mathrm{b}_{\mathrm{R}}=$ insulating; $\mathrm{C}=$ conducting.

${ }^{c}$ Chemical modification to $\mathrm{Li}=$ addition of $100 \mathrm{~g}$ high-purity $\mathrm{AIN}$ powder.

$\mathrm{d}_{\mathrm{Al}}, \mathrm{Li} 3 \mathrm{~N}$ addition: $\mathrm{Al}$ added to $\mathrm{Li}=14.2 \mathrm{~g} ; \mathrm{N}$ added as $\mathrm{Li} 3 \mathrm{~N}$ to $\mathrm{Li}=25.55 \mathrm{~g} ; \mathrm{N}$ in $\mathrm{Li}$ in excess of $\mathrm{AlN}: 825 \mathrm{ppm}$. 


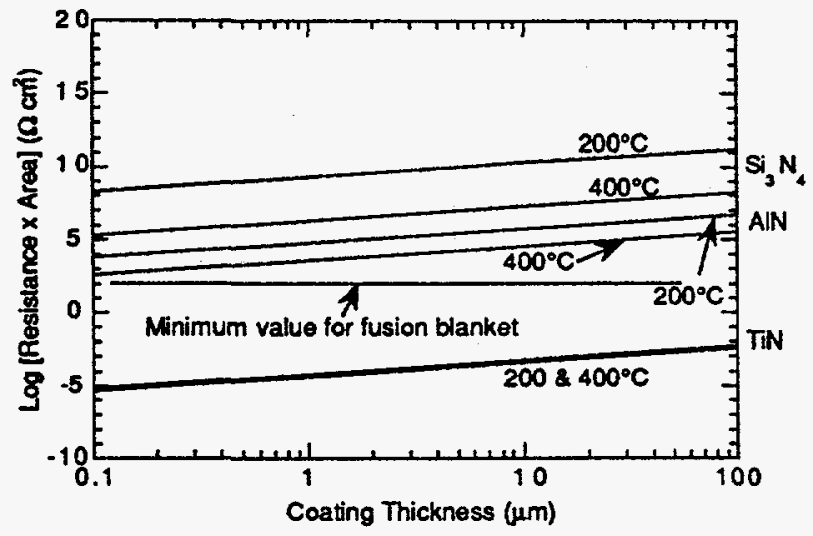

Figure 1. Resistance of $\mathrm{AIN}, \mathrm{Si}_{3} \mathrm{~N}_{4}$, and TiN as a function of coating thickness; requirements for fusion blanket application are shown for reference
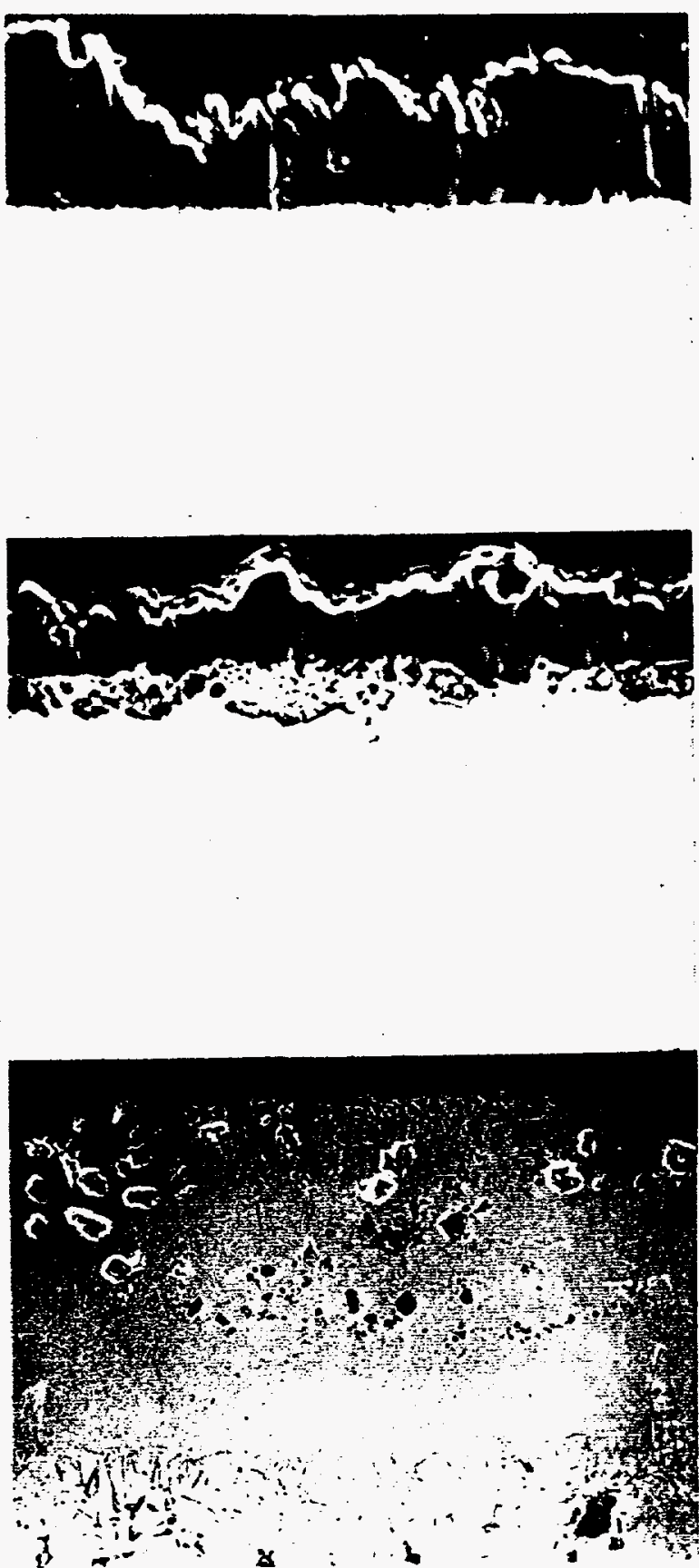

Figure 2. SEM photomicrographs of cross sections of (a) AlN-coating with $900^{\circ} \mathrm{C}$ hardening on V alloy, (b) AlN-coating with $900^{\circ} \mathrm{C}$ hardening on prealuminized $\mathrm{V}$ alloy, and (c) pack diffusion $\mathrm{Al}_{2} \mathrm{O}_{3}$ coating on Type 304 stainless steel, after $5000 \mathrm{~h}$ exposure to $\mathrm{Li}$ environment of normal purity at $300^{\circ} \mathrm{C}$ in Run $2-10$ 

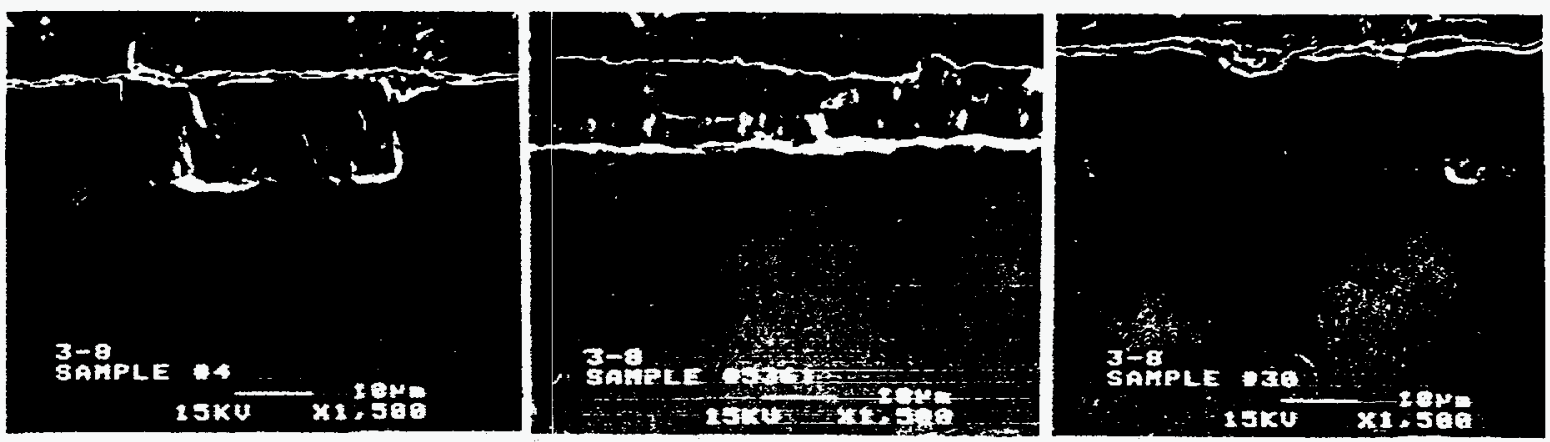

Figure 3. SEM photomicrographs of cross sections of AlN-coated specimens after $120 \mathrm{~h}$ exposure in Run $3-8$ at $500^{\circ} \mathrm{C}$ to $\mathrm{Li}$ environment with $\mathrm{N}$ and $\mathrm{Al}$ additions
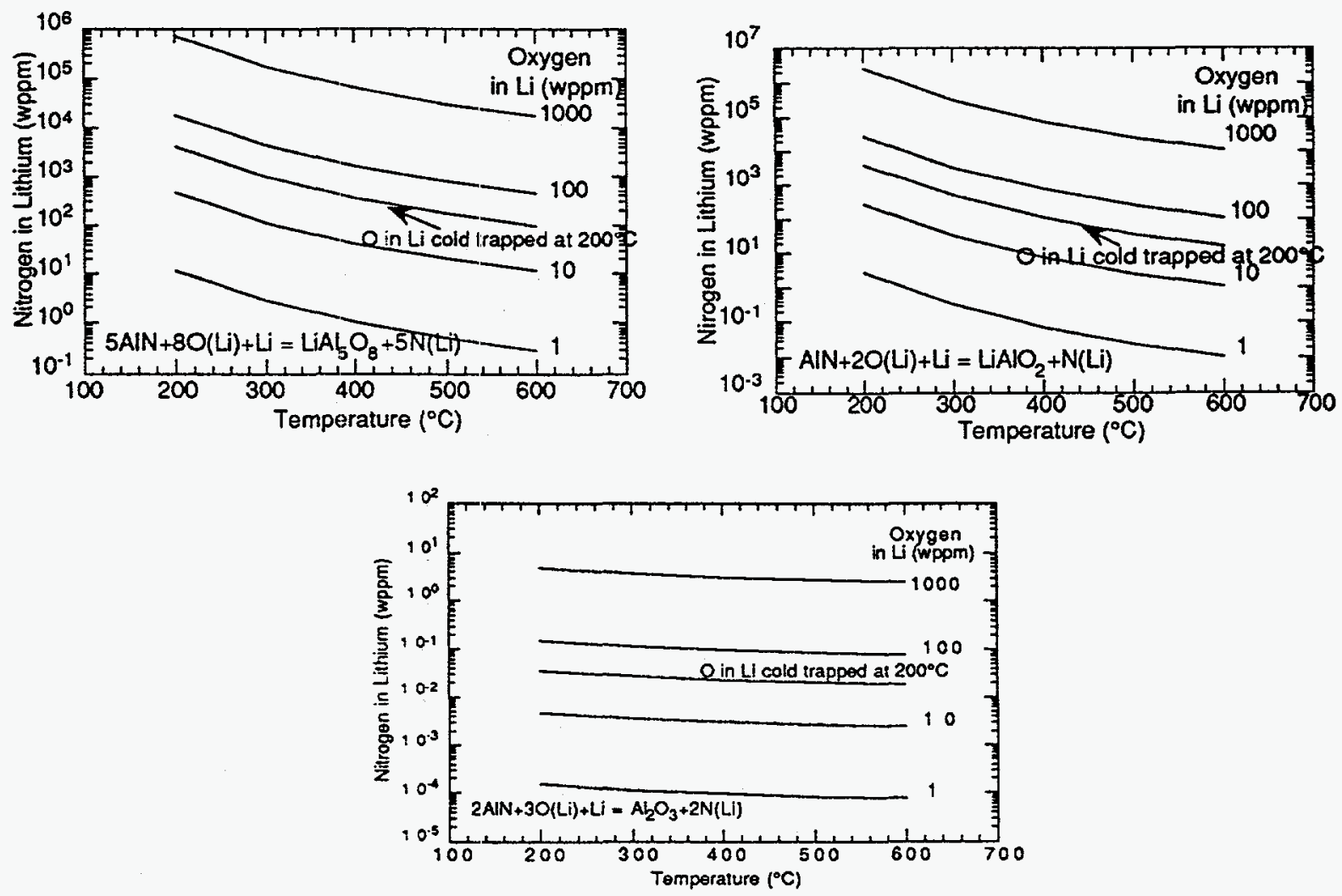

Figure 4. Regions of stability of $\mathrm{AlN}, \mathrm{LiAl}_{5} \mathrm{O}_{8}, \mathrm{LiAlO}_{2}, \mathrm{Al}_{2} \mathrm{O}_{3}$ phases as a function of temperature and $\mathrm{O}$ and $\mathrm{N}$ concentrations in $\mathrm{Li}$ 